\title{
PENGARUH PERSEPSI KEADILAN REMUNERASI \\ TERHADAP KINERJA PELAYANAN PEGAWAI \\ PADA BADAN KEPEGAWAIAN DAERAH PROVINSI JAWA TIMUR
}

Angga Fitri Valina Hartono

M. Nasih

Fakultas Ekonomi dan Bisnis Universitas Airlangga

Email: angga.fivah@yahoo.com

\begin{abstract}
Abstrak
Sampai dengan saat ini remunerasi di lingkungan Pemerintah dirasa masih menimbulkan kecemburuan di antara para pegawai, hal ini terkait juga dengan penilaian kinerja yang dilakukan dengan DP3 yang notabene penilaiannya secara subjektif dan terkesan formalitas saja. Penelitian ini bertujuan menguji pengaruh persepsi keadilan remunerasi yang dirasakan oleh pegawai terhadap kinerja pelayanan yang mereka berikan, baik secara parsial maupun simultan. Penelitian ini menggunakan pendekatan kuantitatif. Hasil penelitian menunjukkan bahwa secara bersama-sama persepsi keadilan remunerasi mempengaruhi kinerja pelayanan pegawai. Semakin tinggi tingkat persepsi pegawai atas keadilan remunerasi maka semakin tinggi kinerja pelayanan yang mereka berikan karena persepsi yang positif akan memberikan dampak yang positif pula terhadap suatu objek. Secara parsial persepsi keadilan distributif dan keadilan prosedural memiliki hubungan yang positif dengan kinerja pelayanan, sedangkan persepsi keadilan interaksional berhubungan negatif dengan kinerja pelayanan. Keadilan distributif menjadi prediktor terbaik dari kinerja pelayanan pegawai.
\end{abstract}

Kata kunci: Keadilan organisasional, remunerasi, kinerja pelayanan

\section{PENDAHULUAN}

Pasal 7 Undang-undang Nomor 43 Tahun 1999 menegaskan bahwa setiap Pegawai Negeri berhak memperoleh gaji yang adil dan layak sesuai dengan pekerjaan dan tanggung jawabnya dan gaji yang diterima oleh Pegawai Negeri harus mampu memacu produktivitas dan menjamin kesejahteraannya. Namun, sampai saat ini remunerasi di lingkungan Pemerintah dirasa masih menimbulkan kecemburuan di antara para pegawai.

Disamping tentang remunerasi, penilaian kinerja yang diterapkan dalam pemerintahan belum mencapai titik optimal. Penilaian kerja melalui DP3 (daftar penilaian pelaksanaan pekerjaan) yang dikeluarkan setiap tahun pada kenyataannya hanya digunakan sebagai syarat kenaikan pangkat saja. Terkesan bahwa penilaian DP3 hanya sekedar formalitas, bahkan nilai yang diberikan seringkali bergantung pada faktor-faktor individual pimpinan (subjektif). Unsur-unsur yang dijadikan dasar penilaian juga sangat sulit diukur keberhasilannya. Akibatnya, hasil penilaiannya tidak mampu membedakan antara PNS yang berkinerja baik dengan yang berkinerja sebaliknya.

Tabel 1.1

Potret kinerja pegawai berdasarkan nilai rata-rata DP3 tahun 2013

\begin{tabular}{|c|c|c|}
\hline Golongan & $\begin{array}{c}\text { Rata-rata } \\
\text { Nilai DP3 }\end{array}$ & Keterangan \\
\hline I & - & - \\
\hline II & 79,58 & Baik \\
\hline III & 81,86 & Baik \\
\hline IV & 82,71 & Baik \\
\hline
\end{tabular}

Sumber: Data internal BKD yang telah diolah 
Catatan:

$\begin{array}{ll}\text { Amat Baik } & 91-100 \\ \text { Baik } & 76-90 \\ \text { Cukup } & 61-75 \\ \text { Sedang } & 51-60 \\ \text { Kurang } & <50\end{array}$

Kuspriyomurdono dalam www.anri.go.id mengemukakan terdapat beberapa bias dan permasalahan dalam pengukuran kinerja menggunakan DP3 seperti penilaian prestasi kerja cenderung dibuat rata-rata dan penilai menghindari penilaian yang bersifat ekstrim; pendapat pribadi penilai tentang karyawannya yang akan berpengaruh dalam pengukuran prestasi kerja; pada kenyataannya proses penilaian pelaksanaan pekerjaan PNS cenderung terjebak ke dalam proses formalitas dan tidak berkait langsung dengan apa yang telah dikerjakan PNS; DP3 PNS secara substantif tidak dapat digunakan sebagai penilaian dan pengukuran seberapa besar produktivitas, kontribusi, keberhasilan dan atau kegagalan PNS dalam melaksanakan tugas pekerjaannya; penilaian DP3 PNS lebih berorientasi pada penilaian kepribadian dan perilaku terfokus pada pembentukan karakter individu dengan menggunakan kriteria behavioral, belum terfokus pada kinerja, peningkatan hasil, produktivitas dan pengembangan pemanfaatan potensi.

BKD yang memiliki tugas mewujudkan upaya reformasi birokrasi dalam penyelenggaraan pelayanan umum (public services) di bidang kepegawaian, seperti penataan, pendistribusian pegawai sesuai dengan kebutuhan dan kompetensinya, kenaikan pangkat pegawai, pemberhentian/pensiun pegawai serta penyediaan data dan informasi kepegawaian, pemberian penghargaan pegawai dan pelayanan kepegawaian lainnya, kerap kali mendapat sorotan jika ada masalah kepegawaian yang terungkap. Tanggung jawab sebagai ujung tombak kepegawaian ini mestinya dimiliki dan diresapi oleh para pegawai sehingga dengan penuh kesadaran melakukan kewajibannya. Kewajiban melayani, bukan dilayani.

Pengujian lebih lanjut yang dilakukan peneliti memiliki harapan supaya kedepannya pelayanan prima benar-benar dapat terwujud di BKD. Peningkatan kesejahteraan pegawai ini memiliki tujuan akhir yaitu para pegawai dapat memusatkan perhatian sepenuhnya untuk melaksanakan tugasnya sesuai dengan bidangnya, sehingga BKD Provinsi Jawa Timur memiliki pegawai yang berkualitas dan dapat menjadi percontohan/pelopor bagi BKD di daerah yang lain.

Berdasarkan latar belakang di atas maka dapat dirumuskan permasalahannya yaitu: 1. Apakah terdapat perbedaan persepsi tingkat keadilan remunerasi antara yang seharusnya dengan yang sesungguhnya terjadi di kalangan pegawai BKD? 2. 
Apakah persepsi terhadap tingkat keadilan distributif remunerasi mempengaruhi kinerja pelayanan pegawai BKD? 3. Apakah persepsi terhadap tingkat keadilan prosedural remunerasi mempengaruhi kinerja pelayanan pegawai BKD? 4. Apakah persepsi terhadap tingkat keadilan interaksional remunerasi mempengaruhi kinerja pelayanan pegawai BKD? 5. Apakah secara bersama-sama persepsi keadilan remunerasi mempengaruhi kinerja pelayanan pegawai BKD?

\section{LANDASAN TEORI}

\section{Penelitian Terdahulu}

Penelitian yang dilakukan oleh Walsh (2003) tentang persepsi karyawan terhadap keadilan dan kepuasan dengan sistem penilaian kinerja yang ada dengan memanfaatkan hipotesis model empat faktor Greenberg dari keadilan organisasi sebagai landasan teori. Penelitian ini dilakukan pada sistem kerja pemerintah yang ada di bagian selatan Amerika Serikat. Hasilnya menunjukkan bahwa persepsi pegawai terhadap sistem penilaian kinerja adalah dilakukan secara adil.

\section{Elamin dan Alomaim (2011) dalam} penelitiannya menguji pengaruh persepsi keadilan organisasional terhadap kepuasan kerja dan kinerja di Arab Saudi. Hasil penelitian menunjukkan bahwa persepsi keadilan berpengaruh terhadap kepuasan kerja. Bagi karyawan asing, semua dimensi keadilan mempunyai pengaruh signifikan terhadap kinerja.

Penelitian Warokka, Gallato, \& Moorthy (2012) menunjukkan hasil bahwa keadilan interaksional lebih berpengaruh daripada jenis lain dari keadilan organisasional dalam mengevaluasi kinerja karyawan. Karyawan lebih peduli pada interaksi selama dan setelah proses evaluasi. Mereka tertarik untuk mengetahui bagaimana mereka telah dievaluasi dan akan ada umpan balik apa setelah proses penilaian kinerja.

Perbedaan dengan penelitian ini yaitu pada tujuan penelitian untuk mengungkap dan menguji persepsi keadilan sistem remunerasi yang diterapkan selama ini di BKD dapat mempengaruhi kinerja pelayanan pegawai. Selain itu, pegawai diminta menilai hasil kerjanya sendiri sesuai dengan kenyataan yang ada. Disini akan lebih difokuskan pada persepsi keadilan itu sendiri sehingga pelayanan yang diberikan pada pengguna jasa dapat ditingkatkan, mengingat setiap orang memiliki ukuran rasa yang berbeda. Oleh karena itu diperlukan suatu ketegasan peraturan yang mendukung dan menjamin bahwa setiap pegawai dapat merasakan keadilan tersebut. Tanpa pilih kasih, terbuka dan penuh pertimbangan. 


\section{Remunerasi}

Widyastuti (2010) mendefinisikan

remunerasi PNS sebagai sitem penggajian yang dikaitkan dengan sistem penilaian kinerja dengan tujuan untuk memacu prestasi dan motivasi kerja PNS. Sasaran remunerasi mendorong peningkatan profesionalisme dan kinerja PNS serta dorongan untuk tidak melakukan korupsi. Uraian dalam Peraturan Pemerintah Nomor 69 Tahun 2010 tentang Tata Cara Pemberian dan Pemanfaatan Insentif Pemungutan Pajak Daerah dan Retribusi Daerah bagian Penjelasan, menjelaskan remunerasi adalah tambahan penghasilan yang diberikan untuk meningkatkan kinerja.

Sistem remunerasi dapat dikatakan berawal dari Undang-undang Nomor 43 Tahun 1999 tentang Pokok-pokok Kepegawaian (Behrens \& Paramitha, 2011), sasarannya adalah peraturan yang adil dan layak terkait dengan upah pegawai dengan beban kerja dan tanggung jawab, kemudian menghubungkan remunerasi dengan pola karir, deskripsi pekerjaan, dan penilaian kinerja. Mondy, Noe (1993), dan Hasibuan (2007) dalam Sancoko (2010) mengemukakan beberapa indikator remunerasi sebagai berikut:

1. Nilai remunerasi dibanding dengan instansi pemerintah lainnya
2. Nilai remunerasi dibanding kinerja yang diberikan

3. Nilai remunerasi dibanding senioritas dalam daftar pegawai

4. Nilai remunerasi dibanding pengalaman yang dimiliki

5. Nilai remunerasi dibanding level (grade yang dimiliki)

6. Nilai remunerasi dibanding potensi yang dimiliki

7. Nilai remunerasi dibanding kebutuhan yang harus dipenuhi

\section{Teori Persepsi}

Menurut Soleh (2005), persepsi merupakan penilaian terhadap suatu fenomena-fenomena yang muncul di lingkungan sekitarnya. Pendapat yang lain dari Dewantoro (2012) menyimpulkan bahwa persepsi merupakan suatu proses individu dalam menyeleksi, mengatur dan menginterpretasikan masukan dan pengalaman yang diterima dan menafsirkannya menjadi gambaran yang berarti.

Proses persepsi merupakan penentu kuat perilaku. Menurut Messer dan White (2006) dalam Matlala (2011), persepsi karyawan terhadap keadilan mempengaruhi kemungkinan mereka untuk menunjukkan perilaku dalam organisasi. Jika dirasakan ketidakadilan dan ketidakefektifan dari sistem manajemen kinerja dapat mengakibatkan kontraproduktif dan kadang-kadang perilaku 
merugikan oleh karyawan. Persepsi yang baik terhadap suatu objek yang dihadapi dapat memunculkan kesimpulan dan perilaku yang baik pula, namun begitu sebaliknya. Persepsi karyawan tentang keadilan dan efektivitas sistem kinerja sering dibentuk oleh bagaimana mereka memandang sikap manajer mereka, pemahaman dan penerapan sistem serta budaya organisasi itu (Matlala, 2011).

\section{Keadilan Organisasi}

Keadilan organisasi dapat didefinisikan sebagai studi tentang keadilan di tempat kerja (Byrne \& Cropanzano, 2001 dalam Walsh, 2003) yang menggambarkan persepsi keadilan perlakuan yang diterima individu atau kelompok dari suatu organisasi dan reaksi perilaku mereka atas persepsi tersebut (Greenberg, 1993 dalam Elamin dan Alomaim, 2011). Cropanzano, Bowen dan Gilliland (2007) berpendapat banyak penelitian telah menunjukkan bahwa pegawai menilai tiga peristiwa dari tempat kerjanya, yaitu keadilan hasil (keadilan distributif), keadilan dari proses alokasi resmi (keadilan prosedural), dan keadilan interpersonal transaksi yang mereka hadapi dengan orang lain (keadilan interaksional).

\section{Keadilan Distributif}

Keadilan distributif adalah keadilan organisasi atas hasil yang diterima pegawai dari organisasi, sehubungan dengan kontribusi yang diberikan ke organisasi (Erlijana, 2006). Demikian pula Noe et al. (2011) dalam Kristanto (2013) menyebutnya sebagai keadilan imbalan yang didefinisikan sebagai penilaian yang dibuat orang terkait imbalan yang diterimanya dibanding imbalan yang diterima orang lain yang menjadi acuannya. Kosep keadilan distributif ini bisa dikatakan berakar Keadilan distributif diukur dengan (Niehoff and Moorman, 1993 dalam Erlijana, 2006) beberapa indikator berikut:

a. Imbalan sesuai dengan prestasi kerja

b. Imbalan sesuai dengan beban kerja

c. Imbalan sesuai dengan tanggung jawab yang diberikan

d. Beban kerja dan jadwal kerja ditentukan secara adil

e. Secara keseluruhan, imbalan yang diterima adalah adil

\section{Keadilan Prosedural}

Keadilan prosedural mempengaruhi kepercayaan pegawai tentang organisasi secara keseluruhan (Cropanzo, Bowen dan Gilliland, 2007). Keadilan prosedural mengacu pada keadilan yang dirasakan dari prosedur yang digunakan untuk membuat keputusan (Colquitt \& Greenberg, 2003 dalam Heslin dan Walle, 2009). Keadilan prosedural 
dapat diukur dengan (Niehoff and Moorman, 1993 dalam Erlijana, 2006) beberapa indikator berikut:

a. Pengambil keputusan memiliki prosedur formal yang diberlakukan konsisten untuk semua orang dan dari waktu ke waktu.

b. Pengambilan keputusan terbebas dari kepentingan yang menguntungkan kelompok atau individu tertentu.

c. Pengambilan keputusan didasarkan kepada informasi yang akurat dan lengkap.

d. Prosedur pengambilan keputusan, ada upaya untuk melibatkan pihak-pihak yang berkepentingan ikut memberikan masukan.

e. Keputusan yang diambil, memberikan kesempatan untuk dikoreksi, manakala terjadi kesalahan.

f. Keputusan yang diambil, senantiasa memperhatikan etika dan norma yang berlaku.

\section{Keadilan Interaksional}

Keadilan interaksional memusatkan perhatian pada bagaimana memperlakukan orang lain dengan penuh hormat dan martabat (Cropanzano, Bowen, \& Gilliland, 2007; Kristanto, 2013). Seperti halnya yang dikemukakan oleh Bies dan Moag (1986) dalam Walsh (2003) dimana keadilan interaksional sebagai kewajaran perlakuan antarpribadi yang salah satunya menerima dari pihak yang berwenang selama berlakunya proses organisasi dan distribusi hasil.
Menurut Tyler (1989, 1994) dalam Damayanti dan Suhariadi (2010) hal penting yang patut diperhatikan adalah semakin baik kualitas perlakuan penguasa terhadap anggotanya maka interaksinya dinilai makin adil; netralitas dapat tercapai bila dasar-dasar dalam pengambilan keputusan menggunakan fakta dan bukan opini, yang objektif dan validitasnya tinggi.

Keadilan Interaksional diukur dengan (Moorman, 1991 dalam Erlijana, 2006) beberapa indikator berikut:

a. Atasan memperlakukan pegawai dengan baik dan penuh pertimbangan

b. Atasan menunjukkan perhatiannya terhadap hakhak saya sebagai pegawai

c. Atasan memberikan umpan balik dengan segera atas keputusannya dan implikasi-implikasi yang menyertainya.

d. Atasan menggunakan kriteria yang konsisten dalam mengambil keputusan yang berhubungan dengan pegawai.

e. Atasan bersikap objektif, menggunakan fakta yang sebenarnya dalam mengambil keputusan yang berhubungan dengan pegawai.

\section{Kinerja Pelayanan}

Pelayanan yang secara umum didambakan (Moenir, 2010) adalah adanya kemudahan dalam 
pengurusan kepentingan; mendapatkan pelayanan yang wajar; mendapatkan perlakuan yang sama tanpa pilih kasih; serta mendapatkan perlakuan yang jujur dan terus terang. Kelancaran suatu layanan atas hak tersebut tergantung pada kesadaran para petugas terhadap kewajiban yang dibebankan; sistem, prosedur dan metode yang memadai; pengorganisasian tugas pelayanan yang tuntas; pendapatan pegawai yang cukup untuk kebutuhan hidup minimal; serta kemampuan/keterampilan pegawai dan sarana kerja yang memadai. LAN-RI (1993) dalam Pasolong (2010) menjelaskan bahwa kinerja adalah gambaran mengenai tingkat pencapaian pelaksanaan suatu kegiatan, program, kebijaksanaan dalam mewujudkan sasaran, tujuan, misi, dan visi organisasi. Berdasarkan kinerja ini dapat diketahui seberapa jauh kemampuan pegawai dalam melaksanakan tugasnya.

Menurut Sampara dalam Sinambela (2010) pelayanan adalah suatu kegiatan atau urutan kegiatan yang terjadi dalam interaksi langsung antarseseorang dengan orang lain atau mesin secara fisik dan menyediakan kepuasan pelanggan. Pelayanan merupakan penggerak utama bagi operasionalisasi kegiatan bisnis (Ibrahim, 2008).

Surjadi (2009) mengemukakan dalam sebuah pelayanan diperlukan adanya keadilan (equity) serta kejujuran atau keterbukaan (fairness). Kata kuncinya adalah respek, yakni menambahkan sesuatu yang tidak dapat dinilai dengan uang, yaitu ketulusan dan integritas dari penyedia layanan, baik petugas maupun kebijakan organisasi publik tersebut (Ibrahim, 2008).

Tujuan utama dari pelayanan adalah kepuasan penerima layanan. Supaya mereka puas maka petugas harus dapat memenuhi 4 persyaratan pokok, yaitu: tingkah laku yang sopan; cara menyampaikan sesuatu yang berkaitan dengan apa yang seharusnya diterima oleh orang yang bersangkutan; waktu menyampaikan yang tepat; dan keramahtamahan. Peraturan Pemerintah Nomor 30 Tahun 1980 tentang Kewajiban Pegawai Negeri Sipil juga telah menegaskan yaitu pada butir n) memberikan pelayanan dengan sebaik-baiknya kepada masyarakat menurut bidang tugasnya masingmasing.

Menurut Semil (2005) terdapat sembilan indikator untuk menilai kinerja pelayanan publik dari birokrasi pemerintah, yaitu:

1. Keterbukaan, dibagi menjadi 3 sub indikator, yaitu keterbukaan prosedur layanan, keterbukaan persyaratan pelayanan, dan keterbukaan biaya pelayanan. 
2. Kemudahan, dibagi menjadi 3 sub indikator, yaitu kemudahan alur pelayanan, kemudahan memperoleh pelayanan dan kemudahan mengakses tempat pelayanan.

3. Kepastian, dibagi menjadi 4 sub indikator yaitu kepastian biaya pelayanan, kepastian waktu pelayanan, ketepatan waktu penyelesaian sesuai standar dan kepastian/kejelasan petugas yang memberikan pelayanan.

4. Keadilan, yang hanya berkaitan dengan perasaan adil atau perlakuan yang sama ketika menerima pelayanan.

5. Profesionalisme Petugas, terbagi menjadi 6 sub indikator yaitu kedisiplinan petugas, tanggung jawab petugas, kemampuan petugas, kecepatan pelayanan, kesopanan dan keramahan petugas serta kejujuran petugas (tidak pungli).

6. Sarana dan Fasilitas, dibagi menjadi 3 sub indikator yaitu ketersediaan sarana dan fasilitas, kenyamanan yang dirasakan dan ketersediaan fasilitas penunjang.

7. Keamanan, dibagi menjadi 2 sub indikator yaitu keamanan lingkungan dan sarana serta perasaan aman dalam pelayanan.

8. Kompensasi, dibagi menjadi 2 sub indikator yaitu ketersediaan kompensasi dan kepuasan yang dirasakan.
9. Sistem Penanganan Keluhan, dibagi menjadi 2 sub indikator yaitu ketersediaan sistem penanganan keluhan dan kepuasan yang dirasakan.

\section{METODE PENELITIAN}

Penelitian ini menggunakan jenis penelitian kuantitatif. Penelitian dilakukan di kantor Badan Kepegawaian Daerah Provinsi Jawa Timur, yang merupakan tonggak urusan kepegawaian di lingkungan Pemerintah Provinsi Jawa Timur.

Populasi yang digunakan adalah seluruh PNS di Badan Kepegawaian Daerah Provinsi Jawa Timur yang terlibat langsung dalam proses pelayanan bagi pengguna jasa, yaitu sejumlah 93 pegawai. Pengambilan sampel dilakukan dengan teknik sampling jenuh.

Variabel independen dalam penelitian ini adalah persepsi keadilan sistem remunerasi. Sedangkan variabel dependen dalam penelitian ini adalah kinerja pelayanan. Persepsi keadilan sistem remunerasi diartikan sebagai tanggapan pegawai atas pemberian tambahan penghasilan yang diberikan pada mereka sebagai bentuk imbalan dari kontribusinya terhadap pencapaian tujuan organisasi yang disesuaikan dengan beberapa faktor seperti, bobot kerja, resiko, lingkungan kerja, penilaian kinerja, tingkat kebutuhan, keterampilan, 
kemampuan, tingkat inflasi, dan sebagainya. Kinerja pelayanan diartikan sebagai kemampuan melakukan atau memenuhi sesuatu yang diharapkan oleh seseorang yang berkepentingan atas suatu layanan melalui adanya interaksi sehingga kebutuhannya dapat tercukupi secara adil.

Metode pengumpulan data yang digunakan adalah primer dan sekunder. Guna menguji hipotesis maka dilakukan beberapa pengujian seperti t-test dan analisis regresi berganda yang sebelumnya harus dilakukan pengujian seperti uji normalitas, uji validitas dan reliabilitas. Berdasarkan rumusan masalah dan uraian di atas maka dapat dirumuskan hipotesis sebagai berikut:

1. Terdapat perbedaan persepsi tingkat keadilan remunerasi antara yang seharusnya dengan yang sesungguhnya terjadi di kalangan pegawai.

2. Persepsi terhadap tingkat keadilan distributif remunerasi mempengaruhi kinerja pelayanan pegawai.

3. Persepsi terhadap tingkat keadilan prosedural remunerasi mempengaruhi kinerja pelayanan pegawai.

4. Persepsi terhadap tingkat keadilan interaksional remunerasi mempengaruhi kinerja pelayanan pegawai.
5. Secara bersama-sama persepsi keadilan remunerasi berpengaruh terhadap kinerja pelayanan pegawai.

\section{ANALISIS DAN PEMBAHASAN HASIL PENELITIAN}

\section{Karakteristik Responden}

Kuesioner telah disebar kepada responden yang berjumlah 93. Jumlah tersebut sesuai dengan jumlah pegawai yang berstatus PNS dan melakukan pelayanan langsung di BKD. Penyebaran kuesioner ini dilakukan oleh penulis sendiri dengan bantuan key person. Namun dalam rentang waktu yang telah ditentukan, sejumlah pegawai tidak memungkinkan untuk mengisi atau mengembalikan kuesioner yang penulis berikan karena alasan cuti, sakit, ijin, ditugaskan ke luar (tidak ada di tempat), maupun sibuk mempersiapkan kegiatan yang akan berlangsung dalam waktu dekat. Jumlah subjek yang berhasil diperoleh dan dapat dianalisis adalah sebanyak 61 orang PNS.

Berdasarkan hasil kuesioner, subjek didominasi oleh pegawai dengan usia antara 30 hingga 39 tahun yaitu sebanyak 20 orang $(32,8 \%)$, tetapi jumlah itu tidak terpaut jauh dengan jumlah usia di bawah 30 tahun maupun usia 40 hingga 55 tahun yang berarti jumlah pegawai berdasarkan usia di BKD bisa dikatakan seimbang. Pegawai di BKD 
masih berada dalam masa produktif. Usia yang produktif, ditambah banyaknya pengalaman, BKDpun mulai melakukan upaya untuk meregenerasi SDM aparaturnya dengan pegawai yang usianya masih muda, tujuannya agar dapat memberikan pelayanan yang lebih baik, cepat dan tepat.

Selain itu, masa kerja responden didominasi pada 20 hingga 29 tahun masa pengabdian yaitu sebanyak 26 orang $(42,6 \%)$. Hal ini menunjukkan dengan masa kerja tersebut dapat dipastikan pegawai di BKD telah memiliki pengalaman yang memadai dalam menjalankan pekerjaan sesuai dengan tugas pokok dan fungsinya, tentu saja pengetahuannya juga semakin luas, dengan demikian karakteristik ini merupakan nilai tambah bagi kualitas pegawai di BKD sehingga kinerja organisasi dapat ditingkatkan.

Responden terbanyak memiliki tingkat pendidikan tertinggi S1, yaitu 31 orang $(50,8 \%)$. Semakin lama pegawai di BKD dituntut untuk mengenyam pendidikan setinggi mungkin. Oleh karena itu setiap tahunnya dibuka kesempatan bagi pegawai yang berminat mengikuti tugas belajar ke jenjang S2 atau dapat mengajukan ijin belajar dengan biaya sendiri. Hal ini ditujukan supaya SDM aparatur di BKD memiliki kualitas dan bisa diandalkan, baik dalam pengetahuan, moral, keterampilan, dan kemampuan
Responden juga didominasi oleh pegawai yang berpangkat/golongan III/a hingga III/d, yaitu sejumlah 47 orang $(77,1 \%)$, yang berarti bahwa tingkat kesejahteraan pegawai di BKD relatif merata. Tingkat pendapatan yang diterimakan pada masingmasing pegawai disesuaikan dengan pangkat dan golongannya.

\section{Analisis Deskriptif}

Berdasarkan tabel 5.5, diketahui bahwa jumlah responden adalah 61, dari 61 responden ini diperoleh nilai rata-rata keadilan sistem remunerasi yang seharusnya adalah 92,44 dengan nilai terendah sebesar 74 dan tertinggi 116 . Sedangkan nilai ratarata keadilan sistem remunerasi yang sesungguhnya adalah 85,77. Nilai tertinggi yang diperoleh yaitu 104 dan nilai terendah 71 .

Tabel 5.5 Statistik Deskriptif

\begin{tabular}{|l|r|r|r|r|}
\hline & \multicolumn{1}{|c|}{ N } & \multicolumn{1}{c|}{ Min } & \multicolumn{1}{c|}{ Max } & \multicolumn{1}{c|}{ Mean } \\
\cline { 2 - 5 } & Statistic & Statistic & Statistic & Statistic \\
\hline KSR Seharusnya & 61 & 74 & 116 & 92,44 \\
KSR Sesungguhnya & 61 & 71 & 104 & 85,77 \\
Kinerja Pelayanan & 61 & 74 & 111 & 89,70 \\
Valid N (listwise) & 61 & & & \\
\hline
\end{tabular}

Kemudian nilai rata-rata kinerja pelayanan sebesar 89,70. Nilai tertinggi yang diperoleh 111 dan yang terendah 74. Nilai rata-rata keadilan sistem remunerasi yang seharusnya dengan yang sesungguhnya diperoleh hasil yang berbeda, keduanya terpaut 6,67. 


\section{Analisis Statistik}

\section{Uji Normalitas}

Berdasarkan uji normalitas dengan menggunakan analisis grafik histogram dan probability plot yang tertera pada lampiran, maka dapat diketahui bahwa keduanya memberikan pola distribusi yang normal dan berbentuk simetris tidak melenceng ke kanan atau ke kiri. Pada grafik normal probability plot, titik titik menyebar berhimpit di sekitar diagonal dan hal ini menunjukkan bahwa residual terdistribusi secara normal. Agar lebih akurat maka uji Kolmogorov - Smirnov juga dilakukan, hasilnya sebagai berikut:

Tabel 5.6.

Uji Kolmogorov-Smirnov

One-Sample Kolmogorov-Smirnov Test

\begin{tabular}{|c|c|c|}
\hline & $\begin{array}{c}\text { KSR } \\
\text { Sesungguhnya }\end{array}$ & $\begin{array}{c}\text { Kinerja } \\
\text { Pelayanan }\end{array}$ \\
\hline $\begin{array}{ll}\mathrm{N} \\
\text { Normal Parameters } \\
& \text { Std. Deviation } \\
& \text { Absolute } \\
\text { Most Extreme } & \text { Positive } \\
\text { Differences } & \text { Negative } \\
& \text { Kolmogorov-Smirnov Z } \\
\text { Asymp. Sig. (2-tailed) }\end{array}$ & $\begin{array}{r}61 \\
85,77 \\
7,419 \\
, 102 \\
, 102 \\
-, 076 \\
, 798 \\
, 547\end{array}$ & $\begin{array}{r}61 \\
89,70 \\
8,844 \\
, 145 \\
, 145 \\
-, 077 \\
1,130 \\
, 155\end{array}$ \\
\hline
\end{tabular}

Nilai K-S untuk variabel keadilan sistem remunerasi yang sesungguhnya sebesar 0,798 dengan probabilitas signifikansi 0,547 dan nilainya jauh di atas 0,05 , hal ini berarti bahwa variabel ini terdistribusi secara normal. Begitu juga dengan nilai K-S variabel kinerja pelayanan sebesar 1,130 dengan probabilitas signifikansi 0,155 yang berarti bahwa variabel ini terdistribusi normal.

\section{Uji Validitas}

Uji validitas digunakan untuk mengukur sah atau valid tidaknya suatu kuesioner. Uji signifikansi dilakukan dengan membandingkan nilai $\mathrm{r}$ hitung dengan $\quad \mathrm{r}_{\text {tabel, }}$, dengan tingkat signifikansi $5 \%$. Uji signifikansi dilakukan dengan $(\mathrm{df})=\mathrm{n}-2$, yaitu $61-$ $2=59$ maka diperoleh $\mathrm{r}_{\text {tabel }}=0,254$. Berdasarkan hasil perhitungan pada setiap pernyataan yang diajukan pada responden mengenai persepsi keadilan remunerasi, menunjukkan bahwa keseluruhan item pernyataan dianggap valid untuk dijadikan alat ukur persepsi keadilan remunerasi karena nilai $\mathrm{r}_{\text {hitung }}>\mathrm{r}$ tabel dengan nilai positif.

Nilai $r_{\text {hitung }}$ tertinggi ada pada item nomor 9 yaitu imbalan sesuai dengan beban kerja sebesar 0,658. Nilai $\mathrm{r}_{\text {hitung }}$ terendah sebesar 0,307 yaitu pada item nomor 18 dengan pernyataan pengambilan keputusan didasarkan pada informasi yang akurat. Persepsi pegawai terkait dengan imbalan yang mereka terima ternyata sudah sesuai dengan beban kerja yang diberikan kepada mereka. Menurut persepsi pegawai, selama ini hal-hal yang terkait dengan pengambilan keputusan dilakukan atas dasar informasi yang akurat, namun di sini pada posisi terendah. 
Begitu juga dengan hasil perhitungan setiap item pernyataan responden pada variabel kinerja pelayanan yang menunjukkan bahwa keseluruhan item tersebut dianggap valid untuk dijadikan alat ukur kinerja pelayanan pegawai karena koefisien korelasi $r_{\text {hitung }}>r_{\text {tabel }}$ dengan nilai positif. Nilai $r_{\text {hitung }}$ tertinggi ada pada item nomor 9 sebesar 0,748 yaitu ketepatan waktu penyelesaian sesuai dengan standar. Nilai $r_{\text {hitung }}$ terendah ada pada item nomor 1 sebesar 0,350 yaitu keterbukaan prosedur layanan. Menurut persepsi pegawai, mereka telah berupaya untuk menyelesaikan setiap pekerjaannya dengan tepat waktu sesuai standar yang ada. Pada poin terendah menunjukkan bahwa keterbukaan prosedur pelayanan sudah diusahakan diberikan secara terbuka namun mungkin belum cukup optimal.

\section{Uji Reliabilitas}

Reliabilitas dapat diukur dengan menggunakan uji statistik Cronbach Alpha $(\alpha)$. Suatu variabel dikatakan reliabel jika memberikan nilai Cronbach Alpha > 0,60.

Tabel 5.7.

Rekapitulasi Hasil Uji Reliabilitas Variabel

\begin{tabular}{|c|c|c|c|}
\hline Variabel & Probabilitas & $\alpha$ & Keterangan \\
\hline Persepsi Keadilan & & & \\
Remunerasi (X) & 0,60 & 0,880 & Reliabel \\
Kinerja Pelayanan (Y) & 0,60 & 0,917 & Reliabel \\
\hline
\end{tabular}

Sumber: Perhitungan SPSS versi 21.00

Hasil uji reliabilitas di atas menunjukkan bahwa besarnya nilai alpha pada seluruh variabel lebih besar dari probabilitas. Hal ini berarti seluruh variabel adalah reliabel sehingga dapat digunakan dalam penelitian.

\section{Uji Beda (t-test)}

Uji beda t-test ini digunakan untuk menguji apakah terdapat perbedaan rata-rata dua sample yang berhubungan. Pada tabel 5.8. dapat diketahui bahwa rata-rata keadilan sistem remunerasi yang seharusnya sebesar 92,44 dan rata-rata keadilan sistem remunerasi yang sesungguhnya sebesar 85,77 . Uji $(\mathrm{df})=\mathrm{N}-\mathrm{k}-1$. Dimana $\mathrm{N}$ adlah jumlah sample (61) dan $\mathrm{k}$ adalah jumlah variabel yang digunakan (2) sehingga df $=61-2-1=58$ dengan taraf kepercayaan 95\%. Perbedaan ini signifikan secara statistik, terlihat dari nilai $\mathrm{t}$ statistik 7,535 lebih besar dari t tabel 2,001 .

Tabel 5.8.

Hasil Uji Beda t-test

Paired Samples Statistics

\begin{tabular}{|l|c|c|r|c|}
\hline & Mean & N & $\begin{array}{c}\text { Std. } \\
\text { Deviation }\end{array}$ & $\begin{array}{c}\text { Std. Error } \\
\text { Mean }\end{array}$ \\
\hline KSR Seharusnya & 92,44 & 61 & 11,081 & 1,419 \\
KSR Sesungguhny & 85,77 & 61 & 7,419 &, 950 \\
\hline
\end{tabular}

Paired Samples Test

\begin{tabular}{|c|c|c|c|c|c|c|}
\hline & \multicolumn{3}{|c|}{ Paired Differences } & \multirow{3}{*}{$\mathrm{t}$} & \multirow{3}{*}{$\mathrm{df}$} & \multirow{3}{*}{$\begin{array}{l}\text { Sig. (2- } \\
\text { tailed) }\end{array}$} \\
\hline & \multirow[t]{2}{*}{ Mean } & \multicolumn{2}{|c|}{$\begin{array}{l}\text { 95\% Confidence } \\
\text { Interval of the } \\
\text { Difference }\end{array}$} & & & \\
\hline & & Lower & Upper & & & \\
\hline $\begin{array}{l}\text { KSR Seharusnya- } \\
\text { KSR Sesungguhnya }\end{array}$ & 6,672 & 4,901 & 8,443 & 7,535 & 60 & ,000 \\
\hline
\end{tabular}

\section{Analisis Regresi Berganda}

Tabel-tabel berikut ini menunjukkan hasil perhitungan regresi dengan variabel persepsi keadilan 
sistem remunerasi yang sesungguhnya sebagai variabel independen (X) dan kinerja pelayanan sebagai variabel dependen (Y). Hasil perhitungannya adalah sebagai berikut:

Tabel 5.9.

Koefisien Determinasi

Model Summary ${ }^{\mathrm{b}}$

\begin{tabular}{|l|r|r|r|r|}
\hline Model & R & R Square & $\begin{array}{c}\text { Adjusted R } \\
\text { Square }\end{array}$ & $\begin{array}{c}\text { Std. Error of } \\
\text { the Estimate }\end{array}$ \\
\hline 1 &, $793^{\mathrm{a}}$ &, 629 &, 610 & 5,524 \\
\hline
\end{tabular}

a. Predictors: (Constant), Interaksional, Prosedural, Distributif

b. Dependent Variable: KinerjaPelayanan

Besarnya nilai adjusted $\mathrm{R}$ square yaitu 0,610 yang berarti variabilitas variabel dependen yang dapat dijelaskan oleh variabilitas variabel independen sebesar $61 \%$. Sedangkan sisanya dijelaskan oleh variabel lainnya yang tidak dimasukkan dalam model regresi.

Tabel 5.10.

Uji Signifikansi Simultan (Uji Statistik F)

ANOVA $^{\mathrm{a}}$

\begin{tabular}{|l|c|r|r|c|c|}
\hline Model & $\begin{array}{c}\text { Sum of } \\
\text { Squares }\end{array}$ & df & $\begin{array}{c}\text { Mean } \\
\text { Square }\end{array}$ & F & Sig. \\
\hline Regression & 2953,200 & 3 & 984,400 & 32,257 &, $000^{\mathrm{b}}$ \\
Residual & 1739,488 & 57 & 30,517 & & \\
Total & 4692,689 & 60 & & & \\
\hline
\end{tabular}

a. Dependent Variable: KinerjaPelayanan

b. Predictors: (Constant), Interaksional, Prosedural, Distributif

Tabel 5.10. menunjukkan nilai $\mathrm{F}$ hitung sebesar 32,257 dengan signifikansi 0,000 yang jauh lebih kecil dari 0,05, maka keadilan distributif, keadilan prosedural dan keadilan interaksional secara bersama-sama berpengaruh terhadap kinerja pelayanan.
Tabel 5.11.

Koefisien Determinasi

Coefficients $^{\mathrm{a}}$

\begin{tabular}{|l|r|r|r|r|r|}
\hline \multirow{2}{*}{ Model } & \multicolumn{2}{|c|}{$\begin{array}{c}\text { Unstandardized } \\
\text { Coefficients }\end{array}$} & $\begin{array}{c}\text { Standardized } \\
\text { Coefficients }\end{array}$ & \multirow{2}{*}{$\mathrm{t}$} & \multirow{2}{*}{ Sig. } \\
\cline { 2 - 4 } & \multicolumn{1}{|c|}{$\mathrm{B}$} & $\begin{array}{c}\text { Std. } \\
\text { Error }\end{array}$ & Beta & & \\
\hline (Constant) & 24,328 & 8,376 & & 2,905 &, 005 \\
Distributif & 20,970 & 3,135 &, 814 & 6,689 &, 000 \\
Prosedural & 12,697 & 3,480 &, 389 & 3,649 &, 001 \\
Interaksional & $-12,453$ & 4,076 &,- 407 & $-3,055$ &, 003 \\
\hline
\end{tabular}

a. Dependent Variable: KinerjaPelayanan

Berdasarkan tabel 5.11. diketahui bahwa probabilitas signifikansi untuk keadilan distributif, keadilan prosedural dan keadilan interaksional berada di bawah 0,05 . Hal ini berarti bahwa variabel kinerja pelayanan dipengaruhi oleh keadilan distributif, keadilan prosedural dan keadilan interaksional. Koefisien bernilai positif artinya terjadi hubungan positif antara keadilan distributif dan keadilan prosedural dengan kinerja pelayanan pegawai. Koefisien bernilai negatif maka hubungan antara keadilan interaksional dengan kinerja pelayanan pegawai adalah tidak searah.

\section{Perbedaan Tingkat Keadilan Remunerasi antara} yang Seharusnya dengan yang Sesungguhnya Terjadi

Hasil perhitungan statistik 5.8. menunjukkan bahwa pada hipotesis pertama yang menyatakan bahwa terdapat perbedaan tingkat keadilan remunerasi antara yang seharusnya dengan yang sesungguhnya terjadi dapat diterima. Pegawai merasa 
bahwa tingkat keadilan remunerasi yang selama ini berjalan belum sepenuhnya sesuai dengan yang seharusnya. Sebagaimana yang diungkapkan oleh Sancoko (2010) dan Tahar (2012) bahwa pemberian kompensasi atau remunerasi yang adil sangat dibutuhkan agar dapat memberi motivasi kepada pegawai guna meningkatkan kinerja mereka.

Jika remunerasi yang berjalan saat ini dirasakan kurang adil, maka ada kemungkinan pegawai akan menurun tingkat kinerjanya karena salah satu motivatornya tidak terpenuhi. Hal ini akan dapat berpengaruh pada kinerja pelayanan yang mereka berikan pada pengguna jasa. Terbentuknya remunerasi yang baik akan dapat membuahkan hasil atau kinerja yang baik sekaligus berkualitas dari pekerjaan yang akan dilaksanakan (Tahar, 2012). Oleh karena itu, organisasi perlu lebih mengakui dan menghormati prestasi kerja pegawai serta lebih transparan untuk mengurangi adanya ketidakadilan dari sistem remunerasi.

Pengaruh Persepsi Keadilan Organisasi terhadap Kinerja Pelayanan

Hasil lain penelitian ini menunjukkan bahwa secara keseluruhan persepsi keadilan sistem remunerasi berpengaruh terhadap kinerja pelayanan pegawai. Hal ini sesuai dengan perhitungan statistik pada tabel 5.10. yang juga mendukung hasil penelitian Elamin dan Alomaim (2011), dimana untuk pekerja asing, semua dimensi keadilan mempunyai pengaruh signifikan terhadap kinerja yang dirasakan.

Selain itu, hasil penelitian ini juga mendukung hasil penelitian Walsh (2003) yang menyebutkan bahwa persepsi pegawai terhadap sistem penilaian kinerja adalah dilakukan secara adil. Sehingga hipotesis kelima yang menyatakan bahwa secara bersama-sama persepsi keadilan remunerasi mempengaruhi kinerja pelayanan pegawai dapat diterima.

Perasaan diperlakukan secara adil merupakan bentuk penghargaan dan pengakuan bahwa apa yang dilakukan oleh pegawai untuk kebaikan organisasi itu berharga. Keadilan dapat meningkatkan kinerja (Cropanzano, Bowen dan Gilliland 2007). Keadilan di tempat kerja dapat memprediksi efektifitas karyawan dalam melaksanakan tugasnya. Hubungan yang kuat antara atasan dan bawahan dapat meningkatkan motivasi untuk berprestasi yang lebih tinggi.

Berdasar tabel 5.11. juga dapat disimpulkan bahwa keadilan distributif dan keadilan prosedural memiliki hubungan positif dengan kinerja pelayanan pegawai yang artinya ada pengaruh signifikan antara keadilan distributif dan prosedural dengan kinerja 
pelayanan, sedangkan keadilan interaksional menunjukkan hubungan yang negatif dengan kinerja pelayanan. Pada penelitian ini, keadilan distributif lebih berpengaruh daripada jenis keadilan organisasional lainnya dalam mengevaluasi kinerja pelayanan pegawai. Hornibrook, Fearne dan Lazzarine (2009) dalam Matlala (2011) mengungkapkan, peningkatan persepsi keadilan oleh individu dapat meningkatkan hasil yang relevan dengan organisasi seperti komitmen, kepuasan kerja dan kinerja dan implikasinya, kinerja organisasi.

Pengaruh Persepsi Keadilan Distributif terhadap Kinerja Pelayanan

Berdasarkan jawaban responden pada kuesioner menunjukkan bahwa pegawai di BKD Prov. Jatim lebih mengedepankan rasa adil atas hasil yang diterimakan pada mereka, tentunya sesuai dengan kontribusi yang telah mereka berikan. Persepsi keadilan distributif berkenaan dengan membandingkan apa yang mereka terima dengan yang diterima oleh rekan lain yang setingkat dan hasil yang diperoleh menunjukkan bahwa persepsi tersebut dapat mempengaruhi kinerja mereka. Hal ini sesuai dengan perhitungan statistik pada tabel 5.11. Pemerataan hasil ternyata merupakan faktor yang penting bagi pegawai. Sehingga dengan demikian hipotesis kedua yang menyatakan bahwa persepsi terhadap tingkat keadilan distributif remunerasi mempengaruhi kinerja pelayanan pegawai dapat diterima, dimana hasil penelitian ini sejalan dengan penelitian yang dilakukan oleh Elamin dan Alomaim (2011) dimana keadilan distributif adalah prediktor terbaik dari kinerja yang dirasakan bagi pekerja asing.

Fernandes \& Awamleh (2006) dan Suliman (2007) dalam Warokka, Gallato, \& Moorthy (2012) mengungkapkan bahwa persepsi karyawan pada keadilan distributif itu tercermin dari kepedulian karyawan terhadap distribusi sumber daya dan hasil atau kinerja yang pasti akan mengarah ke efektifitas organisasi. Sistem penilaian kinerja yang dianggap prosesnya tidak adil, akan berpotensi menjadi sumber perselisihan, ketidakpercayaan, tidak hormat, dan masalah sosial lainnya.

\section{Pengaruh Persepsi Keadilan Prosedural terhadap} Kinerja Pelayanan

Persepsi atas tingkat keadilan prosedural juga dirasakan begitu penting bagi pegawai. Berdasarkan perhitungan statistik yang telah diperoleh pada tabel 5.11. menunjukkan bahwa pegawai di BKD Prov. Jatim tidak hanya peduli dengan hasil yang mereka terima tetapi juga dengan kewajaran proses yang digunakan dalam menentukan hasil tersebut. Hal ini mendukung penelitian terdahulu oleh Colquit, 
Conlon, Wesson, Porter, \& Ng (2001) dalam Heslin

\& Walle (2009) yang mengemukakan bahwa persepsi ketidakadilan prosedural dapat mempengaruhi kinerja. Selain itu juga penelitian dari Tyler \& Belliveau (1995) dalam Warokka, Gallato, \& Moorthy (2012) yang menyatakan bahwa dalam konteks pengambilan keputusan organisasi, keadilan prosedural memiliki dampak positif pada berbagai keputusan terkait pegawai dan reaksi emosional serta perilaku mereka yang akan berkonsekuensi dengan kinerja.

Konsistensi atas prosedur yang berlaku baik intern maupun ekstern menjadi perhatian pegawai karena mereka memiliki persepsi bahwa sebagai abdi masyarakat mereka memiliki hak untuk diperlakukan sama. Persepsi keadilan ini dirasa dapat menciptakan perilaku dan sikap yang positif. Melibatkan mereka dalam semua kegiatan yang menyangkut kepentingan mereka akan menjadi langkah yang efektif untuk membuat mereka menjadi lebih bersemangat dalam melaksanakan pekerjaannya. Hipotesis ketiga yang menyatakan bahwa persepsi terhadap tingkat keadilan prosedural remunerasi mempengaruhi kinerja pelayanan pegawai dapat diterima.

\section{Pengaruh Persepsi Keadilan Interaksional} terhadap Kinerja Pelayanan

Terkait dengan persepsi keadilan interaksional, pegawai di BKD Prov. Jatim secara umum merasa bahwa perasaan adil yang mereka peroleh dari suatu interaksi dengan pimpinan kurang maksimal. Hal ini ditunjukkan dengan hasil perhitungan statistik pada tabel 5.11. dimana hubungan persepsi terhadap tingkat keadilan interaksional terhadap kinerja pelayanan pegawai adalah tidak searah. Berbeda dengan jenis keadilan organisasional lainnya. Hal ini bertentangan dengan hasil penelitian Warokka, Gallato, \& Moorthy (2012) yang menyebutkan bahwa keadilan interaksional lebih berpengaruh daripada jenis keadilan organisasional lainnya dalam mengevaluasi kinerja karyawan.

Bagi pegawai keadilan interaksional itu tidak begitu berhubungan dengan tingkat kinerja mereka karena mereka menganggap bahwa selama ini ratarata pimpinan mereka kurang maksimal dalam menjalin komunikasi dengan mereka. Pimpinan mereka hanya memperhatikan urusan dengan pimpinan yang lebih tinggi. Perlakuan yang diberikan kepada pegawai, perhatian terhadap pegawai, umpan balik yang diberikan pada pegawai, dan dalam pengambilan keputusan terkait dengan pegawai 
terkesan biasa saja sehingga mereka melaksanakan pekerjaannya sesuai dengan perintah atasan saja.

Interaksi dengan pegawai seharusnya

menjadi perhatian bagi seluruh jajaran pimpinan. Pimpinan yang care kepada semua pegawai akan mendapat tempat tersendiri di hati pegawainya, akan menjadi motivasi dalam meningkatkan kinerjanya. Umpan balik yang aktif terhadap segala bentuk pendapat dari pegawai akan memunculkan rasa penghargaan bagi mereka, sehingga mereka dapat terpacu dan bersemangat untuk rajin bekerja serta memberikan kontribusi yang terbaik bagi organisasi.

\section{KETERBATASAN PENELITIAN}

1. Responden dari penelitian ini adalah para Pegawai Negeri Sipil yang berada dalam naungan regulasi dengan peraturan-peraturan mengikat yang telah ditetapkan oleh Pemerintah sehingga terdapat keseragaman dalam hal pemberian remunerasi dan terkait dengan validitas pengukuran atau penilaian kinerja yang mengakibatkan tidak banyak teori yang bisa dicantumkan untuk mendukung penelitian.

2. Pengambilan data dilakukan pada satu rentang waktu dengan menggunakan kuesioner sehingga tidak semua sampel dapat memberikan respon terhadap kuesioner tersebut karena berbagai alasan dan kesibukan mereka, dengan demikian subjek yang berhasil diperoleh dan dapat dianalisis adalah sebanyak 61 orang dari 93 orang PNS.

3. Penelitian ini hanya membatasi pada dua variabel yang digunakan yaitu persepsi keadilan sistem remunerasi sebagai variabel bebas dan kinerja pelayanan sebagai variabel terikat.

Sehingga, dengan demikian keterbatasanketerbatasan ini hendaknya dapat menjadi perhatian dan acuan bagi peneliti yang lain untuk dapat menyempurnakannya.

\section{SIMPULAN DAN SARAN}

\section{Simpulan}

1. Terdapat perbedaan tingkat keadilan remunerasi antara yang seharusnya dengan yang sebenarnya terjadi. Keadilan remunerasi yang ada saat ini dirasa belum sesuai dengan yang diharapkan oleh para pegawai.

2. Persepsi terhadap tingkat keadilan distributif remunerasi mempengaruhi kinerja pelayanan pegawai. Hasil ini sesuai dengan temuan pada penelitian Elamin dan Alomaim (2011).

3. Persepsi terhadap tingkat keadilan prosedural remunerasi mempengaruhi kinerja pelayanan pegawai. Hasil penelitian ini mendukung penelitian yang pernah dilakukan oleh Colquit, Conlon, Wesson, Porter, \& Ng (2001) dalam 
Heslin \& Walle (2009), dan Tyler \& Belliveau (1995) dalam Warokka, Gallato, \& Moorthy (2012).

4. Persepsi terhadap tingkat keadilan interaksional remunerasi mempengaruhi kinerja pelayanan pegawai dengan hubungan yang negatif. Hasil ini bertentangan dengan penelitian Warokka, Gallato, \& Moorthy (2012).

5. Secara bersama-sama persepsi keadilan remunerasi mempengaruhi kinerja pelayanan pegawai. Semakin tinggi tingkat persepsi pegawai atas keadilan remunerasi maka semakin tinggi kinerja pelayanan yang mereka berikan karena persepsi yang positif akan memberikan dampak yang positif pula terhadap suatu objek.

\section{Saran}

Saran-saran yang dapat diberikan adalah sebagai berikut:

1. Jika dirasa keadilan remunerasi belum sesuai dengan yang diharapkan oleh pegawai maka sebaiknya sebuah organisasi melakukan evaluasi kembali terhadap kebijakan yang ditetapkan karena hal ini berkaitan dengan apa yang dirasakan pegawai atas yang diberikan oleh organisasi kepadanya sebagai bentuk motivasi dan penghargaan atas hasil kerjanya.
2. Keadilan atas hasil yang diterima dan dirasakan oleh pegawai hendaknya diikuti dengan kesadaran akan tanggungjawabnya untuk memberikan pelayanan yang lebih baik lagi kepada masyarakat (pengguna jasa).

3. Keadilan atas proses remunerasi yang dirasakan oleh pegawai hendaknya menjadikan mereka selalu berusaha untuk mengembangkan diri dan memberikan yang terbaik bagi organisasi.

4. Sebaiknya interaksi antara pimpinan dan pegawai lebih dimaksimalkan karena setiap manusia memiliki hak untuk dihargai dan dianggap keberadaannya. Pegawai bukanlah pesuruh, tapi pegawai adalah abdi Negara yang memiliki peran dalam kemajuan Negara.

5. Sebaiknya dari kedua belah pihak baik organisasi maupun pegawai dapat melaksanakan tugas dan fungsinya dengan lebih baik. Keadilan yang dirasakan bersama akan mengurangi dan bahkan menghilangkan kecemburuan dan keirian serta meningkatkan kinerja.

6. Bagi pihak-pihak yang ingin melakukan penelitian lanjutan diharapkan dapat mengembangkan dan memperluas ruang lingkup serta variabel-variabel yang belum diteliti dalam penelitian ini sehingga hasil dan pembahasannya bisa lebih detail dan luas. 


\section{DAFTAR PUSTAKA}

Andriani, N.P., E. Setyowati, dan F. Nurani. - . The Mechanism of Preparation on Purwodadi Botanical Garden Unit Towards Remuneration. Journal of Public Administration Research (JOPAR). Vol. 1. No.1.

Arikunto, Suharsimi. 2006. Prosedur Penelitian: Suatu Pendekatan Praktik. Jakarta: Rineka Cipta.

Behrens, Christoph and P. Paramitha. 2011. Performance-Based Remuneration For Civil Servants. Jurnal Studi Pemerintahan. Vol. 2 No. 1.

Bergen, C.W.V., and D. Bandow. 2012. Contemporary Workplace Punishment And Discipline Recommendations. International Journal Of Interdisciplinary Research. Vol. 1, No. 1.

Cropanzano, R., D.E. Bowen, and S.W. Gilliland. 2007. The Management of Organizational Justice. Articles. Academy of Management Perspectives.

Damayanti, Komi dan F. Suhariadi. 2010. Hubungan antara Persepsi terhadap Keadilan Organisasi dengan Komitmen Karyawan pada Organisasi di PT Haji Ali Sejahtera Surabaya. Jurnal. Surabaya: Universitas Airlangga.

Danish, R.Q. dan A. Usman. 2010. Impact of Reward and Recognition on Job Satisfaction and Motivation: An Empirical Study from Pakistan. International Journal of Busisness and Management. Vol. 5 No. 2.

Daromes, F. Eduardus. 2006. Pengaruh Keadilan Organisasional terhadap Intensitas Turnover Auditor pada Kantor Akuntan Publik di Indonesia. Tesis. Semarang: Universitas Diponegoro.

Dewantoro, Suryo. 2012. Pengaruh Aspek.Aspek Persepsi Dukungan Organisasi Terhadap Kinerja Pegawai Direktorat Metrologi Kementrian Perdagangan. Tesis. Universitas Gadjah Mada.
Elamin, A.M., and Nasser, Alomaim. 2011. Does Organizational Justice Influence Job Satisfaction and Self-Perceived Performance In Saudi Arabia Work Environment? International Management Review. Vol. 7 No. 1.

Erlijana. 2006. Analisis Pengaruh Keadilan Organisasi terhadap Organizational Citizenship Behavior melalui Variabel Mediator Komitmen Pegawai pada Dinas Kepemudaan dan Keolahragaan Pemerintah Provinsi Jawa Timur. Tesis. Universitas Airlangga.

Ghozali. 2013. Aplikasi Analisis Multivariate dengan Program IBM SPSS 21: Update PLS Regresi. Semarang: Badan Penerbit Universitas Diponegoro.

Harahap, Zairin. 2011. Pelayanan Publik yang Prima Tidak Cukup Hanya Mengandalkan Kebijakan Remunerasi. Jurnal Kebijakan dan Manajemen PNS (Juni): Vol.5, No.1.

Heslin, Peter A., and D.V. Walle. 2009. Performance Appraisal Procedural Justice: The Role of a Manager's Implicit Person Theory. Journal of Management.

Ibrahim, Amin. 2008. Teori dan Konsep Pelayanan Publik Serta Implementasinya. Bandung: Mandar Maju.

Kristanto, Sentot. 2013. Pengaruh Keadilan Organisasional Terhadap Kepuasan Kerja dan Dampaknya Terhadap Komitmen dan Intensi Keluar di PT Indonesia Power UBP Bali. Tesis. Universitas Udayana.

Khan, Saima dan U. Habib. -. Procedural Justice \& Organizational Performance. Abasyn Journal of Social Sciences. Vol. 4 No.1.

Kumorotomo, Wahyudi. 2011. Tunjangan Kinerja Daerah (TKD) dan Upaya Peningkatan Kinerja Pegawai: Kasus Di Provinsi Gorontalo Dan Provinsi Dki Jakarta. Jurnal Kebijakan dan Manajemen PNS (Juni): Vol.5, No.1. 
Matlala, Manoko M. 2011. Employee Fairness Perceptions Of A Performance Management System. Dissertation. University Of South Africa.

Moenir, H.A.S. 2010. Manajemen Pelayanan Umum di Indonesia. Jakarta: Bumi Aksara.

Nasution, S. 2006. Metode Research: Penelitian Ilmiah. Edisi 1, Cetakan ke 8. Jakarta: Bumi Aksara.

Pasolong, Harbani. 2010. Teori Administrasi Publik. Bandung: Alfabeta.

Peraturan Pemerintah Nomor 30 Tahun 1980 tentang Kewajiban Pegawai Negeri Sipil.

Peraturan Pemerintah Nomor 69 Tahun 2010 tentang Tata Cara Pemberian dan Pemanfaatan Insentif Pemungutan Pajak Daerah dan Retribusi Daerah.

Peraturan Pemerintah Nomor 46 Tahun 2011 tentang Penilaian Prestasi Kerja Pegawai Negeri Sipil.

Prasetyani, Nurul. 2009. Analisis Kinerja Pelayanan Publik Perusahaan Daerah Air Minum (PDAM) Kabupaten Demak. Tesis. Semarang: Universitas Diponegoro.

Rawls, John. 2011. A Theory of Justice: Teori Keadilan. Terjemahan. Yogyakarta: Pustaka Pelajar.

Sancoko, Bambang. 2010. Pengaruh Remunerasi terhadap Kualitas Pelayanan Publik. Jurnal Ilmu Administrasi dan Organisasi. Vol. 17. No. 1.

Sekaran, Uma. 2006. Metodologi Penelitian untuk Bisnis. Jakarta: Salemba Empat.

Semil, Nurmah. 2005. Analisis Kinerja Pelayanan Publik Instansi Pemerintah (Studi Kasus di Kantor Pertanahan Kota Semarang). Tesis. Semarang: Universitas Diponegoro.

Sinambela, Lijan Poltak, dkk. 2010. Reformasi Pelayanan Publik. Jakarta: Bumi Aksara.
Soleh, Muhammad. 2005. Hubungan Persepsi Masyarakat tentang Perilaku Birokrasi terhadap Kualitas Pelayanan Publik. Tesis. Jakarta: Universitas Terbuka.

Sugiyono. 2007. Metode Penelitian Kuantitatif, Kualitatif dan $R \& D$. Bandung: Alfabeta.

Surat Edaran Nomor 02 Tahun 2013 tanggal 15 Februari tentang Pelaksanaan Penilaian Prestasi Kerja PNS.

Surjadi. 2009. Pengembangan Kinerja Pelayanan Publik. Bandung: Refika Aditama.

Tahar, Ilham. 2012. Kajian Sistem Remunerasi Berbasis Kinerja (Studi Kasus pada BI). Tesis. Jakarta: Universitas Indonesia.

Taniredja, Tukiran dan Hidayati, Mustafidah. 2012. Penelitian Kuantitatif (Sebuah Pengantar). Bandung: Alfabeta.

Undang-undang Nomor 43 Tahun 1999 tentang Pokok-Pokok Kepegawaian.

Walsh, Marie B. 2003. Perceived Fairness Of And Satisfaction With Employee Performance Appraisal. Dissertation. Louisiana State University.

Warokka, A., C.G. Gallato, and T. a/l Moorthy. 2012. Organizational Justice In Performance Appraisal System And Work Performance: Evidence From An Emerging Market. Journal of Human Resources Management Research. Vol. 2012.

Widyastuti, Yeni. 2010. Pengaruh Persepsi Remunerasi Pegawai, Motivasi Kerja dan Disiplin Kerja Terhadap Kinerja Pegawai di Kantor Pelayanan Perbendaharaan Negara (KPPN) Percontohan Serang Provinsi Banten. Jurnal Administrasi Publik. Vol. 1 No. 2.

Yusuf, M. 2011. 8 Langkah Kreatif Tata Kelola Pemerintah dan Pemerintah Daerah. Jakarta: Salemba Empat.

www.setkab.go.id

www.anri.go.id

www.antaranews.com diposkan pada tanggal 19 Mei 2013. 